\title{
New Approach to Remuneration Policy for Investment Firms: a Polish Capital Market Perspective
}

\author{
Szymon Okoń
}

\begin{abstract}
The experience of the recent financial crisis leads to reflections on the relevant mechanisms of risk reduction of an investment firms activity. Within the European Union, the Directive 2010/76/ EU (CRD III) has introduced new rules regarding the remuneration policy for investment firms. The main goal was to reduce the risk of investment firms' activity. This is a prudential regulation. The purpose of this article is to evaluate, from the point of view of an investment firm, proposed by the EU legislator approach to remuneration policy aimed at reducing the risk of the operation of this type of financial institutions. The aim was to identify the key problems with which Polish investment firms may face in the future in connection with new remuneration policy rules. As far as the methodology is concerned, the author carried out in-depth and standardized interviews with the representatives of several investment firms in Poland. In addition, the method of observation has been applied. The results of the research demonstrates that the abovementioned regulations will have limited impact on reducing the risk of the activities of these financial institutions as well as their implementation will be difficult for them in practice.
\end{abstract}

KEY WORDS: remuneration policy, investment firms, capital markets supervision

JEL Classification: G15, G24

${ }^{1}$ Poznań University of Economics, POLAND

\section{Introduction}

One notable feature of a properly functioning capital market is the stability and safety of its participants. That can be ensured by introducing appropriate regulations. Recently global financial markets have experienced a crisis during which it turned out that the regulations do not work properly in difficult circumstances (Hoshi, 2011; Miele \& Sales 2011; Tropeano, 2011). Therefore, there is time to consider the creation and implementation of solutions functioning properly regardless of the situation on the market. It should be

Corespondence concerning to this article should be addressed to: szymon.okon@ue.poznan.pl noted that the risk profile of operating on the capital market investment firms depends on appropriate remuneration policy. According to that it is proposed to limit the approaches that encourage employees to make decisions leading to the increase of the investment firm's risk. This is an element of limitation of freedom activity carried out by the investment firm in order to ensure properly functioning capital market.

The rules on remuneration policy for investment firms within the European Union were adopted in the Directive of the European Parliament and the Council 2010/76/EU of 24 November 2010 amending Directives 2006/48/EC and 2006/49/EC as regards capital requirements for the trading book and for re-securitisations, and the supervisory review of remuneration policies 

not existed in the UE legal system before. It is worth noting that these regulations do not apply to entities such as investment funds, pension funds, and private equity funds. It is a kind of package requirements, prudential regulations, in order to prevent potential adverse effects of poorly designed remunerations structures for the accuracy of risk management and risk-taking control by individual employees. It obliges investment firms to establish and implement policy and remuneration practices contributing to effective risk management in respect of the particular categories of staff whose professional activities have a significant impact on the risk profile of the investment firm.

\section{Methodology}

The author of the following paper conducted research amongst key investment firms operating in Poland. The author understands the investment firms as brokerage houses, banks conducting brokerage activities, foreign investment firms operating in Poland as well as legal entities with their seats in the member state of OECD or WTO conducting brokerage activities in Poland.

The author carried out in-depth and standardized interviews with the representatives of several investment firms. These interviews were specified in terms of content and conducted using a detailed plan with a list of questions. In addition, the author used the method of observation, i.e. planned observations on investment firms to indicate dependencies that exist between occurring processes and phenomena as well as discrepancies or contradictions.

In the result of the research it was possible to identify the key problems with which Polish investment firms may face in the future in connection with new remuneration policy rules.

\section{Remuneration policy}

In the light of the conducted analysis by the remuneration policy should be understood the policy including salaries and discretionary retirement benefits. This is broader approach because it also includes within its scope some kind of benefits payable to former employees who are retired. It is worth noting that according to the CRD III this policy applies to certain distinct groups of individuals acting within the investment firm, i.e. senior management, risk takers, staff engaged in control functions and any employee receiving total remuneration that takes them into the same remuneration bracket as senior management and risk takers, whose professional activities have a material impact on their risk profile. It can be concluded that the above applies to a part of the wider remuneration system of a particular investment firm. Therefore, these institutions face the challenge of adapting the existing remuneration schemes to the requirements of EU law. This will require taking a series of actions at the operational level, including changes in labour contracts with existing employees.

The body exercising supervisory functions of an investment firm is responsible for the adoption of the remuneration policy and its implementation. Furthermore, its functions include the review of remuneration policy, which should be carried out at least once a year. It should rely on and verify that the solutions correspond to the remuneration policy assumptions, primarily determine whether it contributes to the prevention of excessive risk-taking. The remuneration of persons engaged in the review should not depend in any way from the areas they control. If so, this would lead to a conflict of interest.

Subject to the provisions of CRD III, the investment firms identified as significant one as regards their size, structure or undertaken activities, should establish remuneration committee. It opinions the remuneration policy from the perspective of its impact on the risk profile of the investment firm. Membership on this committee is restricted to persons who do not perform any executive functions in the investment firm. It is the reasonable solution. Otherwise, persons exercising executive functions would evaluate solutions as regards their own remuneration.

\section{Remuneration and capital adequacy}

The remuneration policy may have a significant impact on compliance of capital adequacy requirements by the investment firms. The investment firms are obliged to meet the capital adequacy requirements according to the following UE regulations: Directive of the European Parliament and the Council 2006/48/EC of 14 June 2006 relating to the taking up and pursuit of the business of credit institutions, Directive of the European Parliament and the Council 2006/49/EC of 14 June 2006 on the capital adequacy of investment firms and credit institutions, Directive of the European Parliament and the 

lem with the payment of remuneration in the form of equity rights in a public company, but the difficulties arise in other cases. First, the problem of valuation of the company should be identified. Second, the need to carry out operations with the corporate nature should be indicated, for example, the share capital increase of investment firm to offer equity rights as remuneration for individual employees. However, in this case the use of phantom shares in particular cases would be possible (Lynch \& Perry, 2003; Lamber, Larcker \& Weigelt, 1993). Given the above, it can be concluded that in addition to the payment of remuneration equivalent, non-public investment firms will have to incur additional costs. Furthermore, it is worth noting also other additional risks. In the case of transfer of shares to employees, the ownership structure of investment firm will change by joining of minority shareholders. The various national systems of corporate law may grant them special rights what will enable them to take actions that may adversely affect the proper functioning of the investment firm.

It can be extremely difficult for investment firms to implement at the operational level the remuneration policy taking into account the above requirements. They will have to organize the implementation, not only in the financial scope by ensuring adequate liquidity, but also from corporate point of view, by the adoption of the ownership structure of the investment firm ensuring possibility of remuneration in kind.

\section{Deferred payment of remuneration}

In order to encourage avoiding actions having a negative impact on the risk profile of investment firms the obligation of deferred payment of remuneration has been introduced in the CRD III. The significant part, which is at least $40 \%$ of the variable components of remuneration, should be spread over a period of not less than three to five years, and properly adapted to the nature of the activity, the risks and the activity of the particular employee. It should be noted that in the case of the variable components of a remuneration amounting to a particularly large amount, deferment of the payment shall be at least $60 \%$ of this amount. Deferral period starts from the date of payment of the first part of variable remuneration. However, the rights to such compensation cannot be granted more often than once a year. The reason of the deferred payment of remuner- ation requirement is to reward employees only for the provision of specified results in a long-term perspective. According to the CRD III, the length of deferral period should be determined in accordance with the business cycle, the nature of the activities, risks exposure as well as the activities of employees. It is worth noting that in the light of the above the specification of such term may be difficult or even impossible. Each of the periods mentioned above may be different. The requirement to defer payment of remuneration in comparison with the obligation to pay no less that $50 \%$ of remuneration in the form of financial instruments causes that in deferral period in each year the part of the remuneration is paid in cash and part in the form of financial instruments. This approach may have an impact on reducing the risk of the investment firm due to the fact that employees in making their decisions will seek to take into account long-term interests of the financial institution.

\section{Severance pay}

In accordance with the principles of remuneration, which are aimed at reducing the investment firm's risk, the severance pay caused by termination of the contract should reflect the results achieved by the particular employee over time. The rules for such payments shall be determined in the way that does not reward failure (CRD III). In this case, the above refers primarily to limit the introduction of solutions encouraging to take actions leading to a higher risk than preferred by the owners of investment firm. This negative effect can occur in case of implementation of golden parachutes (Evans \& Hefner, 2009; Singh \& Harianto, 1989; Choi, 2004) causing that employees after leaving the institution receive above-average remuneration regardless of the results already obtained and the level of risk of the investment firm.

\section{Guaranteed variable remuneration}

To encourage jobseekers to employment in particular investment firm by variable remuneration (what in view of new remuneration rules may be limited), the guaranteed payment of variable remuneration has been introduced. The above is exceptional and occurs only in the recruitment of new staff and is limited only to the first year of employment. There is no specification as regards the payment method of such remuneration. 

firms, many limitations and uncertainties regarding payments, may result in a permanent increase of fixed remuneration. Therefore the expectations of employees in this field will probably change. In the opinion of the author, offering higher fixed remuneration by investment firms meeting expectations of employees means that these employees will approach with indifference to variable remuneration and thus it will not be treated as the incentive to limit decisions affecting the growth of the risk of the investment firms. The basic goal of the new remuneration rules will not be probably achieved in this case.

As far as the remuneration policy is concerned, in the opinion of the author, the EU legislature has made too deep harmonization. It is worth noting that, despite the distinctions of the common EU capital market, there are also the capital markets of each Member States and operating within these markets investment firms. Each capital market has its specific characteristics, especially in the meaning of its structure, and participants. Moreover, each capital market is in particular stage of development, what can be observed for example it the size and volume of transactions. The profile of risk of investment firms on mature markets and emerging markets may differ. Therefore, solutions imposing uniform remuneration rules for investment firms aimed at reducing their risk may lead to limitation of activity of those financial institutions that operate on markets which are in development stage.

In the opinion of the author, it is worth noting that the new remuneration policy rules imposed by the CRD III could substantially affect the reduction of activity of local investments firms operating on emerging markets. These financial institutions often have to compete with large financial conglomerates operating across borders. It is much more difficult for local investment firms operating on the emerging capital markets to achieve a relatively high level of revenue. It should be taken into account that new regulations may have impact on the increase of costs. Firstly, because of the need to reorganize the existing remuneration schemes, what is associated with additional efforts, commitment of employees responsible for this area of investment firms, as well as outside consultants. Secondly, as indicated earlier, it appears that the expectations of employees will change and they will be interested in the increase of fixed rather that uncertain and deferred variable part of remuneration. Although, the cost of adapting may by partially passed on the end user (client), this solution seems to be limited. This would probably have negative effects on the dynamic of development of these financial institutions.

\section{References}

1. Aloui, R., Aissa, M., Nguyen, D. (2011). Global Financial Crisis, Extreme Interdependences, and Contagion Effects: The Role of Economic Structure? Journal of Banking and Finance, 35, 130-141.

2. Aseff, J. G., Santos, M. S. (2005). Stock Options and Managerial Optimal Contracts Stock Options and Managerial Optimal Contracts. Economic Theory, 26, 813-837.

3. Barrios, V.E., Blanco, J.M. (2003). The Effectiveness of Bank Capital Adequacy Regulation: A Theoretical and Empirical Approach. Journal of Banking \& Finance, 27, 1935-1958.

4. Blum J. (1999). Do Capital Adequacy Requirements Reduce Risks in Banking? Journal of Banking \& Finance, 23, 755-771.

5. Blum J., Hellwig M. (1995). The Macroeconomic Implications of Capital Adequacy Requirements for Banks. European Economic Review, 39, 739-749.

6. Calem P., Rob R. (1999). The Impact of CapitalBased Regulation on Bank Risk-Taking. Journal of Financial Intermediation, 8, 317-352.

7. Choi A. (2004). Golden Parachute as a Compensation-Shifting Mechanism. Journal of Law, Economics, \& Organization, 20, 170-191.

8. Commission of the European Communities (2009, April 30). Commission Recommendation on Remuneration Policies in the Financial Services Sector. Brussels: Commission of the European Communities. Retrieved from http://ec.europa. eu/internal_market/company/docs/directorsremun/financialsector_290409_en.pdf.

9. Basel Committee on Banking Supervision (2010, January). Compensation Principles and Standards Assessment Methodology. Basel: Bank for International Settlements. Retrieved from http:// www.bis.org/publ/bcbs166.pdf.

10. Basel Committee on Banking Supervision (2010, October). Consultation Report on Range of Methodologies for Risk and Performance Alignment 
of Remuneration. Basel: Bank for International Settlements. Retrieved from http://www.bis.org/ publ/bcbs178.pdf.

11. Evans, J. D., Hefner F. (2009). Business Ethics and the Decision to Adopt Golden Parachute Contracts: Empirical Evidence of Concern for All Stakeholders. Journal of Business Ethics, 86, 65-79.

12. Guo, F., Chen, C. R., Huang, Y. S. (2011). Markets Contagion during Financial Crisis: A RegimeSwitching Approach. International Review of Economics and Finance, 20, 95-109.

13. Committee of European Banking Supervisors (2009, April 20). High-level Principles for Remuneration Policies. Retrieved from http:// www.eba.europa.eu/getdoc/34beb2e0-bdff-4b8e979a-5115a482a7ba/High-level-principles-forremuneration-policies.aspx.

14. Hoshi, T. (2011). Financial Regulation: Lessons from the Recent Financial Crises. Journal of Economic Literature, 49, 120-28.

15. Kirkpatrick (2011). Corporate Governance Lessons from the Financial Crisis. OECD Journal: Financial Market Trends, 2009, 61-87.

16. Krasnik (2011). Regulatory Aspects of Treatment of New Remuneration Policy in EU. Bancni Vestnik, 60, 31-35.

17. Lambert, R. A., Larcker D. F., Weigelt K. (1993). The Structure of Organizational Incentives. Administrative Science Quarterly, 38, 438-461.

18. Markwat, T., Kole, E., Van Dijk, D. (2009). Contagion as a Domino Effect in Global Stock Markets. Journal of Banking and Finance, 33, 1996-2012.

19. Miele, M. G., Sales, E. (2011). The Financial Crisis and Regulation Reform. Journal of Banking Regulation, 12, 277-307.

20. Financial Stability Forum (2009, April 2). FSF Principles for Sound Compensation Practices. Retrievedfromhttp://www.financialstabilityboard. org/publications/r_0904b.pdf.

21. Singh, H., Harianto, F. (1989). Top Management Tenure, Corporate Ownership Structure and the Magnitude of Golden Parachutes Top Management Tenure, Corporate Ownership Structure and the Magnitude of Golden Parachutes. Strategic Management Journal, 10, 143-156.

22. Thakor, A. V. (1996). Capital Requirements,
Monetary Policy, and Aggregate Bank Lending: Theory and Empirical Evidence. Journal of Finance, 51, 279-324.

23. Tropeano, D. (2011). Financial Regulation after the Crisis: Where Do We Stand? International Journal of Political Economy, 40, 45-60.

\section{Regulations}

1. Directive 2010/76/EU of the European Parliament and the Council of 24 November 2010 amending Directives 2006/48/EC and 2006/49/EC as regards capital requirements for the trading book and for re-securitisations, and the supervisory review of remuneration policies (Official Journal of the UE of 14 December 2010, L 329, p.3 as amended).

2. Directive 2006/48/EC of the European Parliament and the Council of 14 June 2006 relating to the taking up and pursuit of the business of credit institutions (Official Journal of the UE of $\mathrm{z} 30$ June 2006, L 177, p. 1 as amended).

3. Directive 2006/49/EC of the European Parliament and the Council of 14 June 2006 on the capital adequacy of investment firms and credit institutions (Official Journal of the UE of 30 June 2006, L 177, p. 201 as amended).

4. Directive 2009/111/EC of the European Parliament and the Council of 16 September 2009 amending Directives 2006/48/EC, 2006/49/EC and 2007/64/ EC as regards banks affiliated to central institutions, certain own funds items, large exposures, supervisory arrangements, and crisis management (Official Journal of the UE of 17 November 2009, L 302 , p. 97 as amended). 